\title{
A comparison of multi-species pasture with ryegrass-white clover pasture under dryland conditions
}

\author{
M.J. DALY ${ }^{1}$, R.M. HUNTER ${ }^{2}$, G.N. GREEN ${ }^{3}$ and L. HUNT ${ }^{1}$ \\ ${ }^{1}$ AgResearch, PO Box 60, Lincoln, Canterbury \\ ${ }^{2}$ Marlborough Research Centre, PB 1007, Blenheim \\ 353 Thompson St, Tinwald, Ashburton
}

\begin{abstract}
The performance of three different multi-species pastures (MSP), or mixed herb leys as they are also known, was compared with that of a standard ryegrass-white clover pasture (cvs Grasslands Super Nui-Grasslands Huia), over a 3-year period at two dryland sites. The MSP treatments had grass and legume species selected for compatibility and growth and aimed to provide a contrast in quality and production. The herb species, common to each of the MSP treatments, were chicory, plantain, sheep's burnet and yarrow. The dry matter production of the MSP treatments was significantly higher than that of the ryegrass-white clover pasture $(\mathrm{P}<0.05)$ in all three years at one site and in one year only at the other site. Seasonal growth comparisons showed higher summer growth $(\mathrm{P}<0.05)$ for MSP treatments compared with ryegrass-white clover and similar autumn growth. Contribution to production of herbage components demonstrated less grass $(\mathrm{P}<0.05)$ and more legume and herbs in the MSP treatments. A lucerne-based MSP gave the best overall performance.
\end{abstract}

Keywords: herbs, legumes, Medicago sativa, feed quality, Trifolium pratense

\section{Introduction}

The New Zealand pastoral industry is characterised by the dominance of ryegrass and white clover pastures (Lancashire 1985). While this combination has been extremely successful as a production base from New Zealand's pastoral sector, there have been some disadvantages resulting from its extensive use. Ryegrass pastures, although tolerant of a wide range of grazing situations and environments, are disadvantaged by low rainfall, high soil temperatures and attack from grass grub and Argentine stem weevil (MacFarlane 1990). Ryegrass cultivars with high endophyte levels (for Argentine stem weevil resistance) can suppress white clover production by $72 \%$ (Sutherland \& Hoglund 1990).
More complex mixtures termed multi-species pastures (MSP), also known as mixed-herb leys (Woodward \& Foster 1987), have the potential to overcome some of the problems commonly associated with ryegrass-based pastures. Multi-species pastures characteristically contain a combination of grasses, legumes and herb species. In contrast to ryegrass-white clover based pastures, which are usually ryegrass dominant, the mix generally includes erect-growing species chosen for compatibility and diversity within the sward. The concept behind multi-species pastures is not new. References as early as 1908 (Elliot) and more recently Woodward \& Foster (1987) in the UK and Musgrave (1989) in New Zealand have supported this type of pasture. While the use of multi-species pastures in New Zealand is small, but common among organic farmers, anecdotal reports from these farmers suggest better animal performance, improved drought tolerance, fewer stock health disorders (such as grass staggers), more uniform seasonal growth patterns and better persistence than ryegrass-white clover pasture. There is, however, a lack of published scientific evidence to support the claims of farmers using this type of pasture.

This project compared the performance of MSP with that of a standard ryegrass-white clover pasture in a dryland environment over a 3 -year period.

\section{Methods}

The performance of three different MSP treatments was compared with that of a standard ryegrass-white clover pasture. The MSP treatments included one containing a comprehensive range of species and two contrasting treatments based around key species within the mixture (Table 1).

The treatments were:

1. Ryegrass standard (perennial ryegrass (high endophyte)-white clover)

1. Comprehensive MSP (combining a wide range of species)

2. Lucerne MSP (Lucerne-based with compatible grasses and herbs )

3. Red clover MSP (Red clover-based with compatible grasses and herbs) 
All MSP treatments contained grasses and legumes selected for compatibility and growth, and aimed to provide a contrast in quality and production. The herb species were common to each of the MSP treatments and comprised chicory, plantain, sheep's burnet and yarrow. The two sites were established in 1992, and both were on shallow soils typical of large areas of dry east coast pastoral farmland.

\section{Sites}

The Mid Canterbury site was established at the Winchmore Research Station. The soil, a Lismore stony silt loam was cultivated and sown on 28 September 1992. The Marlborough site was located at Dashwood, in the Lower Awatere Valley, on a dry subhygrous yellow-brown sandy loam. This site, described in detail by Hunter et al. (1994), was established after cultivating and sowing on 22 September 1992.

Seed of the individual species was combined on a weight basis $(\mathrm{kg} / \mathrm{ha})$ to make up each treatment (Table 1), and sown using a precision Oyjord cone seeder. Fertiliser at Winchmore consisted of $250 \mathrm{~kg} / \mathrm{ha}$ of superphosphate applied at establishment, then annually. Soil fertility results taken in the second year of the trial gave $\mathrm{pH} 6.3, \mathrm{Ca} \mathrm{13,} \mathrm{K} \mathrm{8,} \mathrm{P} \mathrm{30,} \mathrm{Mg} \mathrm{14,}$ $\mathrm{Na} 5, \mathrm{~S} 8$. At Dashwood $100 \mathrm{~kg} / \mathrm{ha}$ of superphosphate (maxi sulphur, 28\%) was applied at establishment then annually. Soil fertility results taken in the second year midway through the trial gave $\mathrm{pH} 6.0, \mathrm{Ca} 9, \mathrm{~K} 27, \mathrm{P} 35$, Mg 35, Na 3, S 9.

The plot size was $14 \times 12 \mathrm{~m}$ at Winchmore and $23 \times 22 \mathrm{~m}$ at Dashwood. Treatments were replicated 4 times and arranged in a randomised block design. Each plot was individually fenced for grazing.

\section{Pasture measurements}

Pasture mass measurements were taken just prior to grazing, using hand clippers and taking four $0.25 \mathrm{~m}^{2}$ quadrat areas per plot cut to a grazing height of $2.5 \mathrm{~cm}$ using a stratified randomisation selection method. Decision to measure and graze the plots were based on herbage mass accumulation and growing conditions. When the treatments were actively growing the plots were harvested when the average mass was visually assessed as $2500-3500 \mathrm{~kg} / \mathrm{ha}$. In winter or summer a lower mass was often taken if growth had ceased due to cold or dry conditions. Separate samples also hand clipped, were taken four times per year (1 in each season) for botanical dissection to identify sown species, weeds and dead matter. Plots were then individually grazed down to grazing height $(2.5 \mathrm{~cm})$ with sufficient sheep (adult ewes) to achieve this within 1-3 days. Periodically some treatments were topped after grazing to bring the treatments back to the standard grazing height $(2.5 \mathrm{~cm})$.

Table 1 Species and sowing rates $(\mathrm{kg} / \mathrm{ha})$ for each treatment at Winchmore and Dashwood sites.

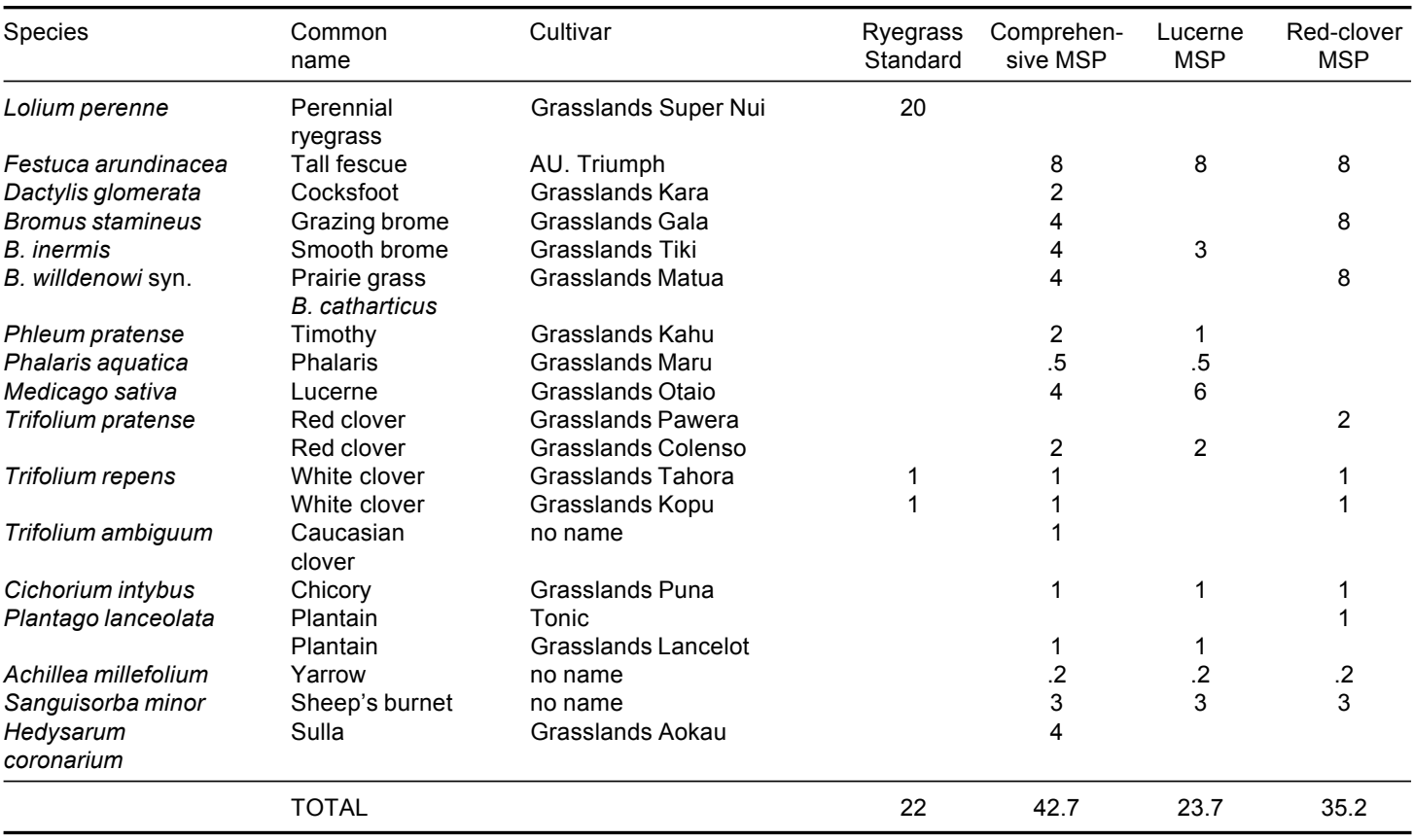


Table 2 Rainfall ( $\mathrm{mm}$ ) recorded at Winchmore Research Station, Mid Canterbury 1992-95 and Dashwood, Marlborough 1992-95.

\begin{tabular}{|c|c|c|c|c|c|c|c|c|}
\hline \multirow[b]{2}{*}{ Months } & \multicolumn{4}{|c|}{---------- Winchmore ---------- } & \multicolumn{4}{|c|}{ 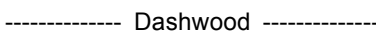 } \\
\hline & $92 / 93$ & $93 / 94$ & $94 / 95$ & Mean $^{1}$ & $92 / 93$ & $93 / 94$ & $94 / 95$ & Mean $^{2}$ \\
\hline Jul & 103 & 1 & 105 & 65 & 8 & 62 & 72 & 71 \\
\hline Aug & 138 & 13 & 9 & 65 & 7 & 65 & 59 & 62 \\
\hline Sep & 101 & 136 & 91 & 50 & 52 & 49 & 72 & 39 \\
\hline Oct & 84 & 26 & 24 & 62 & 5 & 55 & 40 & 42 \\
\hline Nov & 49 & 93 & 38 & 62 & 73 & 46 & 40 & 31 \\
\hline Dec & 74 & 91 & 27 & 68 & 82 & 46 & 40 & 41 \\
\hline Jan & 55 & 54 & 55 & 58 & 50 & 46 & 26 & 46 \\
\hline Feb & 40 & 70 & 31 & 55 & 44 & 31 & 30 & 28 \\
\hline Mar & 58 & 150 & 60 & 68 & 45 & 33 & 53 & 54 \\
\hline Apr & 106 & 18 & 60 & 66 & 56 & 19 & 54 & 61 \\
\hline May & 87 & 29 & 36 & 65 & 68 & 66 & 47 & 63 \\
\hline Jun & 20 & 68 & 259 & 55 & 56 & 35 & 109 & 52 \\
\hline Total & 913 & 747 & 795 & 739 & 546 & 553 & 642 & 590 \\
\hline
\end{tabular}

\section{Results and discussion}

\section{Annual herbage accumulation}

Annual herbage accumulation was higher at Dashwood (Figure 1) than Winchmore, which in part can be explained by higher winter and spring production (Figure 2) attributable to good rainfall conditions during spring in 1993-94 and 1994-95 at Dashwood (Table 2), and also the warmer winter temperatures experienced at this site compared with the cooler inland Winchmore site.

Pasture treatments did not vary greatly in herbage accumulation in the first year (although just reaching significance at Winchmore $\mathrm{P}<0.05)$, but by the second year the MSP treatments were producing significantly more than the ryegrass standard. This trend continued into the third year, although the advantage to the MSP treatments was significantly higher only at the Winchmore site $(\mathrm{P}<0.05)$. Recently in the North Island Ruz-Jerez et al. (1991), comparing a herbal ley (similar to MSP) with ryegrass-white clover in a study over 2 years, found that production was $25-30 \%$ higher for the herbal ley and that late-spring and summer production in particular was higher.

Figure 1 Annual dry matter accumulation at Dashwood and Winchmore over a 3-year period 1992-95. (Error bars represent LSD ${ }_{5}$ ).

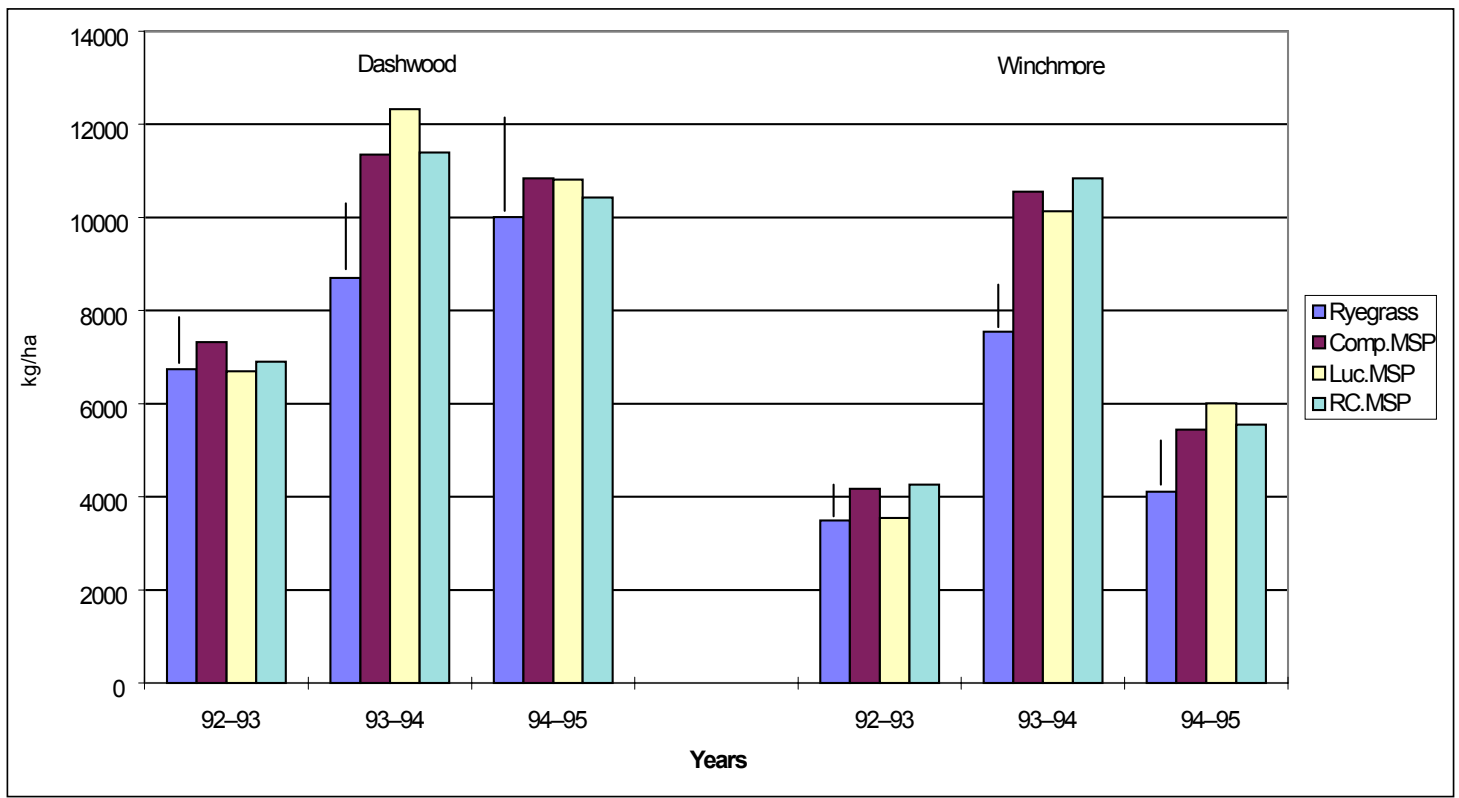


Figure 2 Dry matter accumulation showing mean seasonal yields at Dashwood and Winchmore over a 3-year period 1992-95. (Error bars represent $\mathrm{LSD}_{5}$ ).

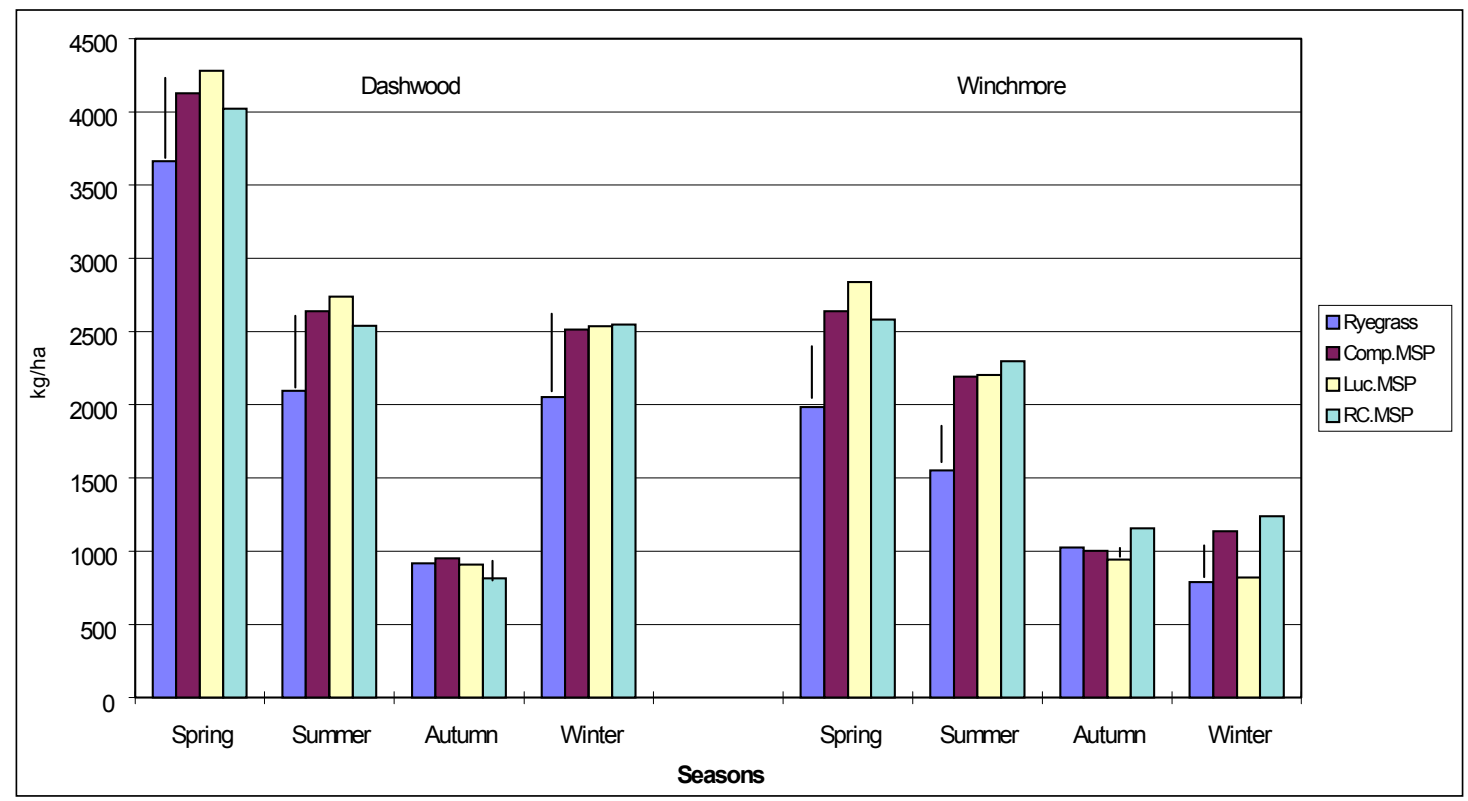

Figure 3 Accumulated total dry matter production and contribution of herbage components at Dashwood and Winchmore over a 3-year period 1992-95.

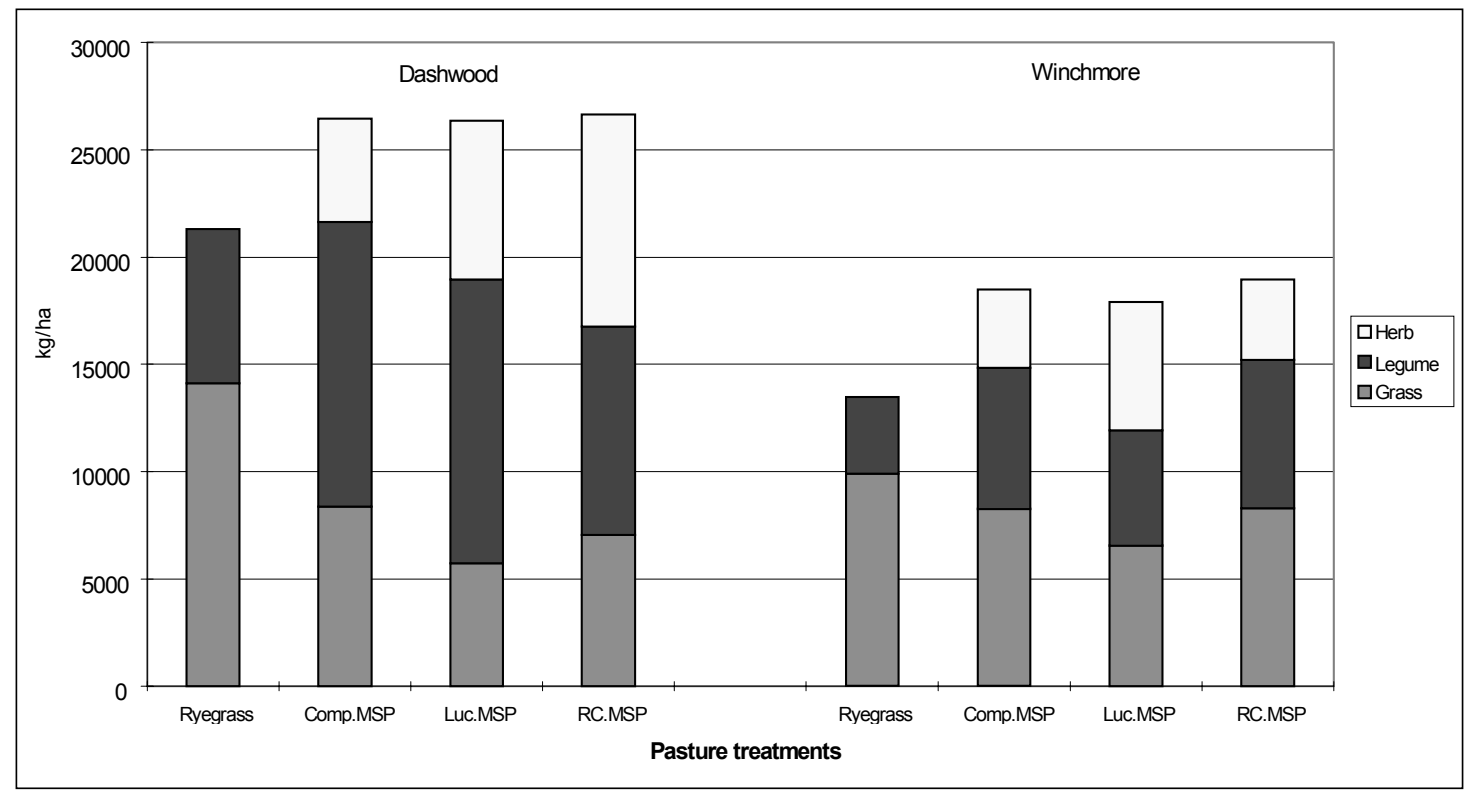

\section{Seasonal accumulation}

The pattern of accumulation for the pasture treatments was consistent across both sites particularly in spring, summer and autumn (Figure 2). The MSP treatments collectively out-produced ryegrass over spring and summer, as was also found by Ruz-Jerez et al. (1991). Growth did not differ in the autumn period, but the winter accumulation gain was higher for the MSP 
treatments except for the Lucerne MSP at Winchmore which yielded less than the other MSP treatments $(\mathrm{P}<0.05)$ but was equal to the ryegrass standard. This may be explained by the cooler winter temperatures and associated lower lucerne growth (White \& Lucas 1990) at this inland site, and the inclusion of more winteractive species in the two contrasting MSP treatments.

\section{Herbage component contributions}

The accumulated dry matter contribution from grass, legume and herb species over the 3-year duration of the trial is given in Figure 3 and demonstrates the higher legume and lower grass content of the MSP treatments compared to the ryegrass standard. Ruz-Jerez et al. (1991) demonstrated that a herbal ley treatment had $30 \%$ more legume on average than a ryegrass-white clover treatment over a 2-year period. In our study this increased legume percentage was partly attributed to the exclusion of high-endophyte ryegrass, which is known to suppress white clover (Sutherland \& Hoglund 1990), and the use of less densely tillered grasses in the sowing mixture, which encourage clover growth (Harris \& Hoglund 1977).

The MSP treatments all had a significant herb component in contrast to the ryegrass standard which had a much higher grass component. The herbs were predominantly chicory and plantain (Daly unpublished data). This combination of chicory, which has a similar feeding value to white clover (Fraser et al. 1988), and plantain, similar in feeding value to high-endophyte ryegrass (Fraser \& Rowarth in press), should in theory provide a relatively better quality feed than the ryegrass treatment. Stevens et al. 1993 found that animal performance increased quadratically with increasing ratios of legume and herb with ryegrass.
The persistence and stability of these treatments are important considerations for farmers evaluating the usefulness of this type of mixture as alternatives to ryegrass pastures. Table 3 indicates the changes in composition over the duration of the trial. In general across all treatments the grass content increased and clover content decreased particularly from the second to third year. The lucerne MSP in the final year of the trial had maintained a relatively high legume content, which was significantly higher than that of ryegrass at Dashwood $(\mathrm{P}<0.05)$ and approaching significance at Winchmore. Herbs tended to remain around $20-30 \%$, with a notable increase in the red clover MSP treatment in the final year. This correlates with the equally notable decrease in legume (largely red clover) over the same period.

These results have shown that combining a range of species, some with different growth periodicity, can improve yield and seasonal growth patterns (Harris \& Hoglund 1977). As species decline or fail to persist with changing conditions, the opportunity for substitution by a lower-order species is more likely within a diverse mixture, allowing continuity of production and quality.

\section{Conclusions}

These trials have demonstrated that multi-species pastures can be considered as a serious option for dryland pastoral farming. The results have shown that as a medium-term pasture, production is higher than for a standard ryegrass-white clover pasture under the conditions at these two sites. The long-term persistence of multi-species pasture has yet to be determined, and further monitoring of this trial will allow better

Table 3 Percentage contribution of herbage components to production at Dashwood and Winchmore over a 3-year period, $1992-95$.

\begin{tabular}{|c|c|c|c|c|c|c|c|}
\hline Component & Treatment & 1992-93 & $\begin{array}{c}\text { Dashwood } \\
\text { 1993-94 }\end{array}$ & 1994-95 & 1992-93 & $\begin{array}{c}\text { Winchmore } \\
\text { 1993-94 }\end{array}$ & 1994-95 \\
\hline \multirow[t]{5}{*}{ Grass } & Ryegrass standard & 51.5 & 45.4 & 67.4 & 60.2 & 63.9 & 72.5 \\
\hline & Comprehensive MSP & 17.2 & 19.8 & 41.6 & 24.6 & 38.8 & 58.1 \\
\hline & Lucerne MSP & 16.8 & 12.7 & 27.6 & 22.5 & 34.9 & 37.0 \\
\hline & Red clover MSP & 28.4 & 17.6 & 34.1 & 29.9 & 38.9 & 50.2 \\
\hline & $\mathrm{LSD}^{5}$ & 7.1 & 7.2 & 18.0 & 4.8 & 6.3 & 10.8 \\
\hline \multirow[t]{5}{*}{ Legume } & Ryegrass standard & 28.4 & 41.1 & 16.8 & 34.4 & 28.5 & 15.7 \\
\hline & Comprehensive MSP & 52.7 & 52.6 & 33.0 & 28.9 & 37.6 & 16.1 \\
\hline & Lucerne MSP & 35.1 & 50.1 & 40.5 & 34.6 & 30.7 & 21.0 \\
\hline & Red clover MSP & 41.7 & 44.6 & 18.0 & 31.8 & 39.8 & 17.8 \\
\hline & $\operatorname{LSD}^{5}$ & 9.2 & 19.5 & 16.6 & 8.1 & 7.8 & 7.2 \\
\hline \multirow[t]{4}{*}{ Herb } & Ryegrass standard & 0.0 & 0.0 & 0.0 & 0.0 & 0.0 & 0.0 \\
\hline & Lucerne MSP & 29.8 & 31.1 & 17.8 & 24.0 & 28.8 & 36.6 \\
\hline & Red clover MSP & 14.3 & 30.8 & 42.2 & 16.6 & 15.4 & 24.6 \\
\hline & LSD $^{5}$ (only for MSP comparison) & 8.3 & 21.3 & 23.5 & 6.1 & 8.4 & 5.3 \\
\hline
\end{tabular}


assessment of their value as a permanent pasture. Though this trial did not specifically measure pasture quality, the high legume component combined with a significant herb contribution in these multi-species pastures would suggest superior feed quality to a standard ryegrasswhite clover pasture, which is likely to translate into better animal performance.

The performance of the three MSP treatments was not markedly different; however the lucerne MSP performed consistently well, maintaining the highest legume content, and therefore warrants recommendation.

Future work on multi-species pastures needs to address long-term persistency and animal performance measurements.

\section{REFERENCES}

Elliot, R.H. 1908. The Clifton Park system of farming. 4th edition. London: Simpkin, Marshal, Hamilton, Kent \& Co. Ltd. (Republished by Faber \& Faber 1943.)

Fraser, T.J.; Cosgrove, G.P.; Thomas, W.J.; Stevens, D.R.; Hickey, M.J. 1988. Performance of Grasslands Puna chicory. Proceedings of the New Zealand Grassland Association 49: 193-196.

Fraser, T.J.; Rowarth, J.S. 1996. Legumes, herbs or grass for animal performance? Proceedings of the New Zealand Grassland Association 58: this issue.

Harris, W.; Hoglund, J.H. 1977. Influences of seasonal growth periodicity and $\mathrm{N}$ fixation on competitive combining abilities of grasses and legumes. Proceedings of the X111 International Grassland Congress: 239-243.

Hunter, R.M.; Knight, T.L.; Hayes, G.; Allan, B.E. 1995. Evaluation of dryland species for lowland Marlborough and Mid Canterbury. Proceedings of the New Zealand Grassland Association 56: 149153.

Lancashire, J.A. 1985. Quality pasture production for the dairy industry. pp. 9-26. In: Philips, T.I. (ed.). The Challenge: Efficient Dairy production. Australian and New Zealand Societies of Animal Production.

MacFarlane, A.W. 1990. Field experience with new pasture cultivars in Canterbury. Proceedings of the New Zealand Grassland Association 52: 139-143.

Musgrave, D. 1989. The mixed herb ley. Soil \& Health March 1989 p22.

Ruz-Jerez, B.E.; Ball, P. Roger.; White, R.E.; Gregg, P.E.H. 1991. Comparison of a herbal ley with a ryegrass-white clover pasture and pure ryegrass sward receiving fertiliser nitrogen. Proceedings of the New Zealand Grassland Association 53: 225-230.

Sutherland, B.L.; Hoglund, J.H. 1990. Effect of ryegrass containing the endophyte Acremonium lolii on associated white clover. Proceedings of the Ist International Symposium on Acremonium-grass interactions 1: 61-71.

Stevens, D.R.; Casey, M.J.; Baxter, G.S.; Millar, K.B. 1993. A response of angora-type goats to increases of legume and chicory content in mixed pastures. Proceedings of the XVII International Grassland Congress: 1300-1301.

White, J.G.H.; Lucas, W.J. 1990. Management of lucerne in cool season. Proceedings of the New Zealand Grassland Association 52: 41-43.

Woodward, L.; Foster, L. 1988. The use of herbal leys in modern organic farming systems. pp. 421-431. In: Allen, P.; van Dusen, D. (eds). Global perspectives on agroecology and sustainable agricultural systems. Proceedings of the 6th International Scientific Conference of the IFOAM, UC Davis Santa Cruz USA. 